Karen L. Price, David A. Long, Nipurna Jina, Helen Liapis, Mike Hubank, Adrian S. Woolf and Paul J. D. Winyard

Physiol Genomics 28:193-202, 2007. First published Sep 19, 2006;

doi:10.1152/physiolgenomics.00147.2006

You might find this additional information useful...

Supplemental material for this article can be found at: http://physiolgenomics.physiology.org/cgi/content/full/00147.2006/DC1

This article cites 45 articles, 19 of which you can access free at: http://physiolgenomics.physiology.org/cgi/content/full/28/2/193\#BIBL

This article has been cited by 6 other HighWire hosted articles, the first 5 are:

Corticosteroid-induced kidney dysmorphogenesis is associated with deregulated expression of known cystogenic molecules, as well as indian hedgehog

S.-K. Chan, P. R. Riley, K. L. Price, F. McElduff, P. J. Winyard, S. J. M. Welham, A. S. Woolf and D. A. Long

Am J Physiol Renal Physiol, February 1, 2010; 298 (2): F346-F356.

[Abstract] [Full Text] [PDF]

Intermolecular Interactions of Sprouty Proteins and Their Implications in Development and Disease

F. Edwin, K. Anderson, C. Ying and T. B. Patel

Mol. Pharmacol., October 1, 2009; 76 (4): 679-691.

[Abstract] [Full Text] [PDF]

HNF1B Mutations Associate with Hypomagnesemia and Renal Magnesium Wasting S. Adalat, A. S. Woolf, K. A. Johnstone, A. Wirsing, L. W. Harries, D. A. Long, R. C.

Hennekam, S. E. Ledermann, L. Rees, W. van't Hoff, S. D. Marks, R. S. Trompeter, K. Tullus, P. J. Winyard, J. Cansick, I. Mushtaq, H. K. Dhillon, C. Bingham, E. L. Edghill, R. Shroff, H.

Stanescu, G. U. Ryffel, S. Ellard and D. Bockenhauer

J. Am. Soc. Nephrol., May 1, 2009; 20 (5): 1123-1131.

[Abstract] [Full Text] [PDF]

Roles of Angiopoietins in Kidney Development and Disease

A. S. Woolf, L. Gnudi and D. A. Long

J. Am. Soc. Nephrol., February 1, 2009; 20 (2): 239-244.

[Abstract] [Full Text] [PDF]

SIX2 and BMP4 Mutations Associate With Anomalous Kidney Development

S. Weber, J. C. Taylor, P. Winyard, K. F. Baker, J. Sullivan-Brown, R. Schild, T. Knuppel, A. M. Zurowska, A. Caldas-Alfonso, M. Litwin, S. Emre, G. M. Ghiggeri, A. Bakkaloglu, O.

Mehls, C. Antignac, E. Network, F. Schaefer and R. D. Burdine

J. Am. Soc. Nephrol., May 1, 2008; 19 (5): 891-903.

[Abstract] [Full Text] [PDF]

Updated information and services including high-resolution figures, can be found at: http://physiolgenomics.physiology.org/cgi/content/full/28/2/193

Additional material and information about Physiological Genomics can be found at: http://www.the-aps.org/publications/pg

This information is current as of March 25, 2010 .

Physiological Genomics publishes results of a wide variety of studies from human and from informative model systems with techniques linking genes and pathways to physiology, from prokaryotes to eukaryotes. It is published quarterly in January, April, July, and October by the American Physiological Society, 9650 Rockville Pike, Bethesda MD 20814-3991. Copyright () 2005 by the American Physiological Society. ISSN: 1094-8341, ESSN: 1531-2267. Visit our website at http://www.the-aps.org/. 


\title{
Microarray interrogation of human metanephric mesenchymal cells highlights potentially important molecules in vivo
}

\author{
Karen L. Price, ${ }^{1 *}$ David A. Long, ${ }^{1 *}$ Nipurna Jina, ${ }^{2}$ Helen Liapis, ${ }^{3}$ \\ Mike Hubank, ${ }^{\mathbf{1}}$ Adrian S. Woolf, ${ }^{\mathbf{1}}$ and Paul J. D. Winyard ${ }^{\mathbf{1}}$ \\ ${ }^{1}$ Nephro-Urology and ${ }^{2}$ Molecular Haematology Units, University College London Institute of Child Health, London, United \\ Kingdom; and ${ }^{3}$ Department of Pathology \& Immunology, Washington University Medical School, St. Louis, Missouri
}

Submitted 10 July 2006; accepted in final form 15 September 2006

Price KL, Long DA, Jina N, Liapis H, Hubank M, Woolf AS, Winyard PJ. Microarray interrogation of human metanephric mesenchymal cells highlights potentially important molecules in vivo. Physiol Genomics 28: 193-202, 2006. First published September 19, 2006; doi:10.1152/physiolgenomics.00147.2006.-Many molecules have been implicated in kidney development, often based on experimental animal studies with organ cultures and cell lines. There are very few studies, however, that have directly addressed equivalent living human embryonic tissues. We generated renal mesenchymal cell lines from normal human metanephroi and used a microarray strategy to define changes in gene expression after stimulation with growth factors which enhance nephrogenesis in rodents. Changes were observed in 1) genes modulating diverse general cellular processes, such as matrix metalloproteinase 1 and stanniocalcin 1 ;2) genes previously implicated in organogenesis e.g., sprouty 4 and midline 1; and 3) genes involved in blood vessel growth, including angiopoietin 1 and 4. Expression of these same genes was subsequently confirmed in vivo. Our novel data have identified several previously unhighlighted genes that may be implicated in differentiation programs within early human nephrogenesis.

leukemia inhibitory factor; mesenchyme; nephrogenesis

THE HUMAN METANEPHROS INITIATES at $5 \mathrm{wk}$ gestation and comprises ureteric bud epithelium and mesenchyme. Mutual inductions between these two lineages lead to normal kidney development (41). Additionally, mesenchyme gives rise to stromalinterstitial tissues and contributes to the vasculature. Defects in the interactions between the mesenchyme and ureteric bud give rise to congenital anomalies such as dysplastic kidneys that have either no functioning nephrons or significant nephron deficits with incomplete differentiation and metaplasia (42).

The identification of human mutations linked to renal malformations have elucidated some information about key genes involved in nephrogenesis, but most detailed functional data derive from mutant or transgenic mice and murine organ culture experiments. Further studies have utilized rodent renal precursor cells (3): for example, transforming growth factor (TGF)- $\beta$ superfamily members and fibroblast growth factors (FGF) modulate ureteric bud growth (9), whereas a growth factor cocktail including leukemia inhibitory factor (LIF) promotes differentiation of renal mesenchyme $(4,27)$.

There are very few studies, however, that have directly addressed equivalent living human embryonic tissues. Burrow

\footnotetext{
* K. L. Price and D. A. Long contributed equally to this work.

Article published online before print. See web site for date of publication (http://physiolgenomics.physiology.org).

Address for reprint requests and other correspondence: P. J. D. Winyard, Nephro-Urology Unit, UCL Institute of Child Health, 30 Guilford St., London, UK (email p.winyard@ich.ucl.ac.uk).
}

and Wilson (8) isolated cells from 12- to 14-wk gestation metanephroi, demonstrating that an (undefined) factor secreted by the G401 renal tumor line enhanced proliferation. Drummond et al. (14) generated several immortalized cell lines, with mesenchymal or epithelial phenotypes, from first trimester metanephroi. Dekel et al. (12) used metanephroi, isolated just a few weeks after inception of the organ, demonstrating continued differentiation after xenotransplantation.

We previously generated renal mesenchymal cell lines from first trimester human metanephroi, which expressed nephrogenic molecules including Wilms' tumor 1 (WT1) and glial cell line-derived neurotrophic factor (GDNF) (28). Herein, we used a microarray-based strategy to define changes in gene expression after stimulation with growth factors considered to enhance nephrogenesis in rodent studies (4). After stimulation, changes were observed in genes that have hitherto not been implicated in human kidney development: expression of these same genes was subsequently confirmed in vivo. Our novel data define several genes that may be important in early stages of human nephrogenesis.

\section{METHODS AND MATERIALS}

All reagents were obtained from Sigma Chemical (Poole, UK) unless otherwise stated. Experiments were all approved by the Institute's Ethical Committee.

Cell culture. The normal human metanephric cell line was generated from a 10-wk gestation fetus, as previously described (28). The kidneys were diced and placed in Dulbecco's modified eagle medium/ Hams F12 (1:1) mix (Invitrogen, Paisley, UK) supplemented with 5\% fetal calf serum (FCS; Invitrogen), epidermal growth factor (10 $\mathrm{ng} / \mathrm{ml}$ ), hydrocortisone (36 ng/ml) 3,3',5-Triiodo-L-thyronine sodium salt $(4 \mathrm{pg} / \mathrm{ml})$, insulin-transferrin-selenium liquid medium supplement $(100 \times)$, penicillin $\mathrm{G}(1,000 \mathrm{U} / \mathrm{l})$, streptomycin $(1 \mathrm{mg} / \mathrm{ml})$, and amphotericin $(25 \mathrm{mg} / \mathrm{ml})$. Cells were cultured at $37^{\circ} \mathrm{C}$ in a $5 \% \mathrm{CO}_{2}$ incubator, medium was changed twice weekly, and confluent cells were passaged $1: 3$ or $1: 5$. To assess potential differentiation, cells were grown to $70 \%$ confluence, serum-starved for $24 \mathrm{~h}$, and then treated with either serum-free medium alone (control group, $n=3$ ) or serum-free medium with LIF (20 ng/ml), FGF2 (50 ng/ml), and TGF- $\alpha(10 \mathrm{ng} / \mathrm{ml})$ (treated group; $n=3)$. We elected 1$)$ to propagate cells on tissue culture plastic, as the most basic substrate; 2) to use defined, serum-free media, to avoid confounding, unknown influences in serum; 3) to use concentrations of LIF, FGF2, and TGF- $\alpha$ based on studies in which rat mesenchymes were stimulated to differentiate (4); and 4) to stimulate cells with LIF, FGF2, and TGF- $\alpha$ for $72 \mathrm{~h}$ because murine mesenchyme shows evidence of differentiation after this period (4).

Microarray analysis. We used $5 \mu \mathrm{g}$ of RNA isolated from control and treated cells with Tri-reagent for microarray analysis and assessed it on the Bioanalyser 2100 (Agilent Technologies, Palo Alto, CA). cDNA and subsequent cRNA synthesis was then performed as described (17). Purified cRNA transcripts were fragmented and hybrid- 


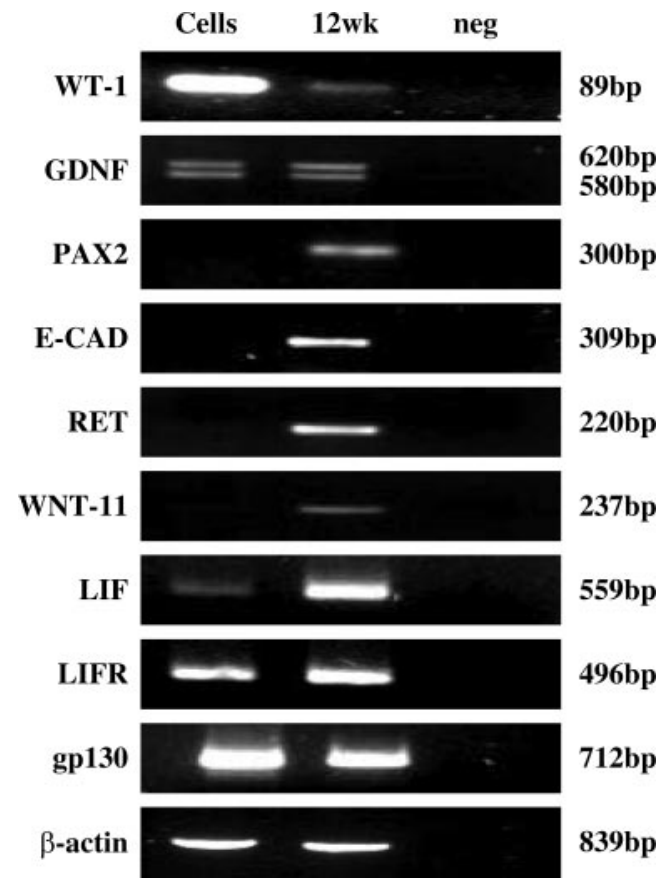

Fig. 1. RT-PCR characterization of the metanephric mesenchymal cell line. Unstimulated cells (Cells) expressed Wilms' tumor 1 (WT1), glial cell line-derived neurotrophic factor (GDNF), leukemia growth factor (LIF), leukemia growth factor receptor (LIFR), and gp130 but not PAX2, E-cadherin, RET, or WNT11. All genes were expressed in a 12-wk gestation metanephros (12 wk). Negative controls are also shown.

ized to human U133 plus 2.0 GeneChips according to Affymetrix standard protocols (http://www.affymetrix.com) ( $n=3$ for control and treated cells at 3 days). Signal values were calculated using MAS 5.0, scaled to 100 and normalized to the median prior to analysis with
GeneSpring 7.2 software (Agilent Technologies). Genes were excluded if the signal strength did not significantly exceed background values and if expression did not reach a threshold value for reliable detection [based on the relaxed Affymetrix MAS 5.0 probability of detection; $P \leq 0.1$ (31)], in all three of either the control or treated chips. Finally, genes were excluded if the level of expression between control and treated cells did not vary by $>1.8$-fold. The resulting gene lists were statistically analyzed by the Wilcoxon-Mann-Whitney test, with a $P$ value cut-off at 0.05 , and applying the Benjamini and Hochberg false discovery multiple testing correction. The data presented in table form show the mean relative values for genes on three chips. Functional categories for genes were assigned using gene ontology terms from the Gene Ontology Consortium (www.geneontology.com).

$R T$-PCR. RT-PCR was performed to characterize human metanephric cells and later to confirm the presence of selected genes altered in the microarray in extracts from whole metanephroi between 9 and 12 wk gestation. The primers used are listed in Supplementary Tables 1 and 2 (the online version of this article contains supplemental material). cDNA was prepared from $1 \mu \mathrm{g}$ of total RNA according to the provider's instructions (Bio-Rad Laboratories, Hemel Hempstead, UK). A $25-\mu 1$ final volume reaction was set up containing $1 \mu \mathrm{l}$ cDNA product, $1.5 \mathrm{mM} \mathrm{MgCl} 2,200 \mu \mathrm{dNTP}$, iTaq buffer $(200 \mathrm{mM}$ Tris $\cdot \mathrm{HCl} \mathrm{pH} 8.4,500 \mathrm{mM} \mathrm{KCl}), 100 \mathrm{nM}$ of both forward and reverse primers, and 1.25 units of iTaq DNA polymerase (Bio-Rad Laboratories). PCR amplifications were performed on a DNA Engine Dyad (MJ Research, Waltham, MA). Negative controls of reactions without cDNA template were included. The housekeeping gene, $\beta$-actin, was used as a loading control. In the case of matrix metalloproteinase 1 (MMP1) and plasminogen activator (urokinase), an additional set of commercially available primers was also used (Tebu-Bio, Peterborough, UK). Validation of alterations in expression of selective genes from the microarray was sought by quantitative real-time RT-PCR. RNA was prepared from control and treated cells of three independent experiments, and all measurements were then performed in duplicate. Quantitative real-time RT-PCR was performed on a PTC-200 DNA
Fig. 2. Immunohistochemistry of the LIF axis in 1st-trimester metanephroi. Sections of 10wk-old human fetal kidneys were counterstained with hematoxylin: positive immunohistochemical signal is brown. $A$ : LIF detected in capsule and ureteric bud branches. $B$ : LIFR detected in nephrogenic mesenchyme and stromal cells. C: gp130 detected in subsets of cells in nephrogenic mesenchyme, stroma, and ureteric bud branches. $D$ : negative control. Bar is $50 \mu \mathrm{m}$.
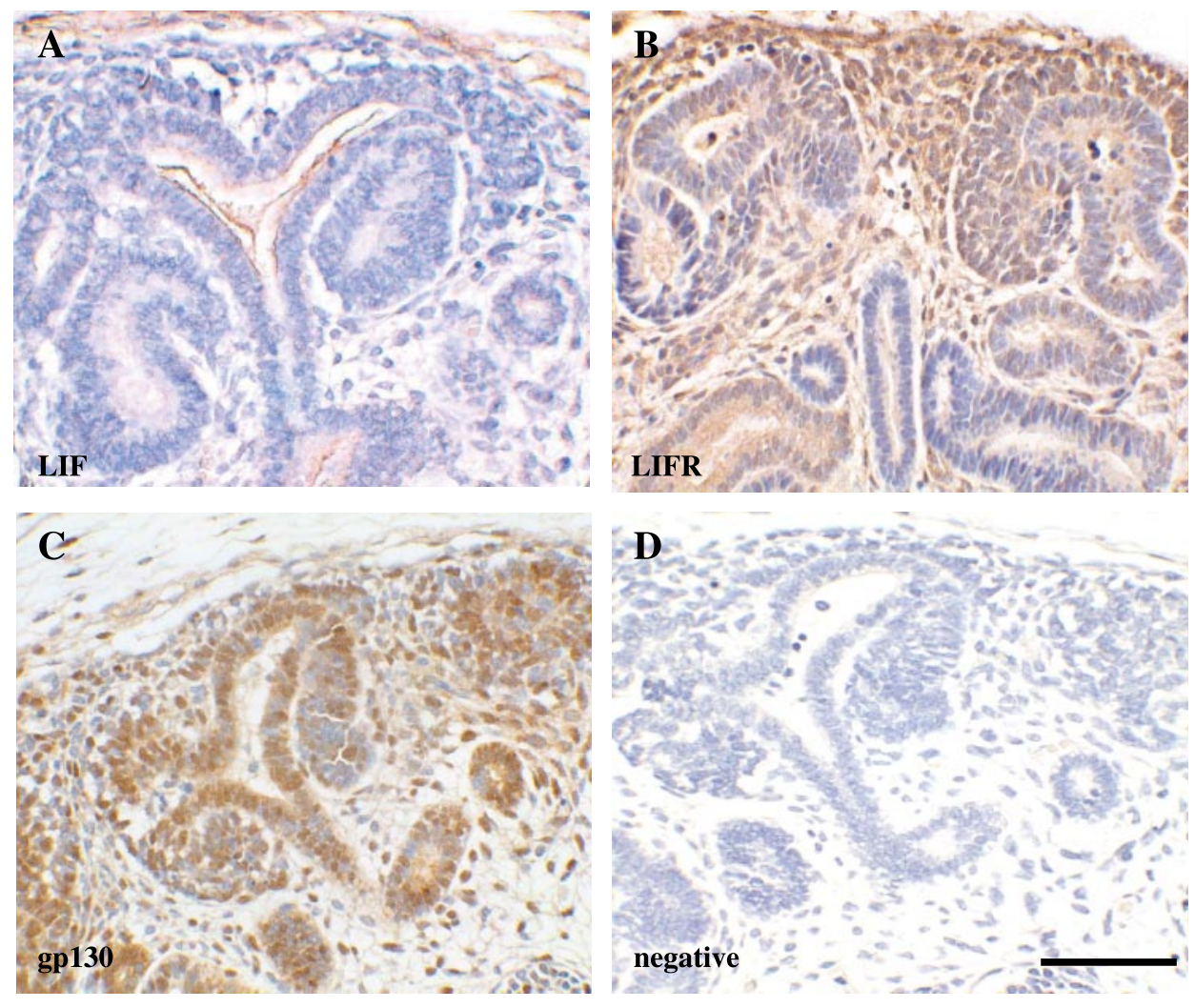

Physiol Genomics • VOL $28 \cdot$ www.physiolgenomics.org 

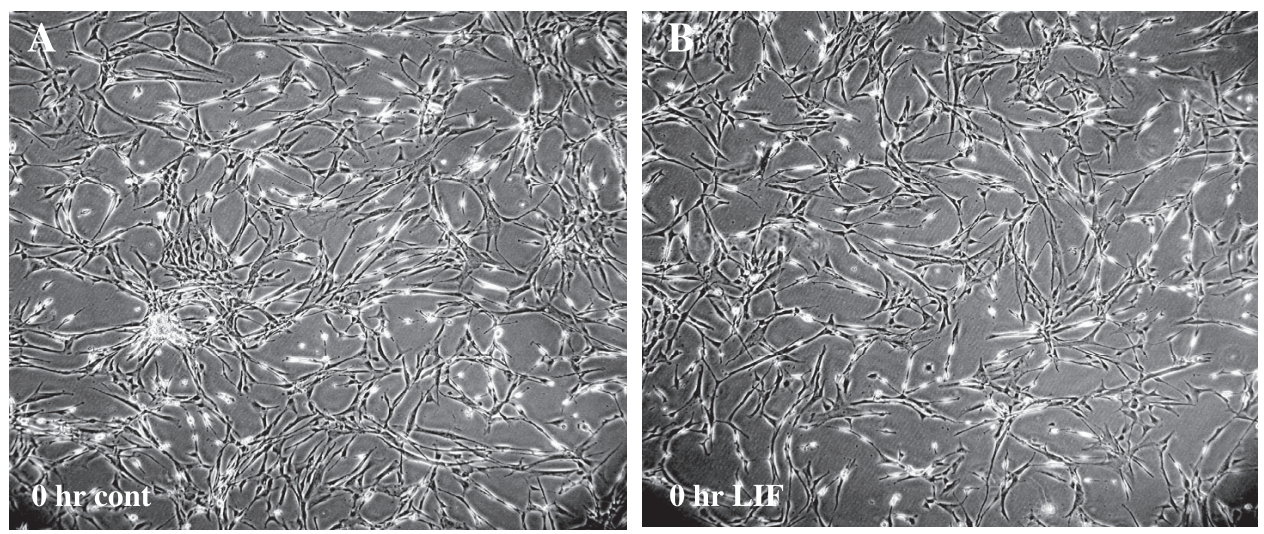

Fig. 3. Human renal mesenchymal cells in culture. Parallel cultures at start of observation period $(0 \mathrm{~h} ; A$ and $B)$ and after three days $(72 \mathrm{~h} ; C$ and $D)$, in basal media (cont; $A$ and $C$ ) or exposed to the growth factor cocktail of LIF, fibroblast growth factor
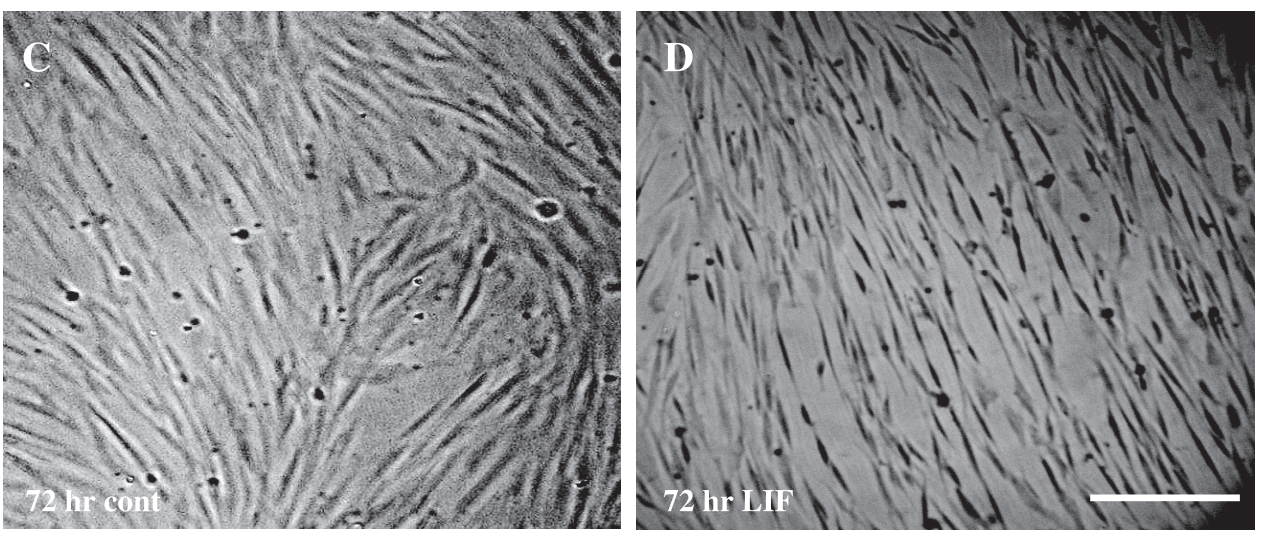
(FGF)2, and transforming growth factor (TGF)- $\alpha$ (LIF; $B$ and $D$ ). Note that cells become confluent over the 3 days and that those exposed to the growth factor cocktail appear more aligned. Bar is $50 \mu \mathrm{m}$ in $A$ and $B$, and $20 \mu \mathrm{m}$ in $C$ and $D$.

Engine Opticon System (MJ Research) for all of the primers listed in Supplementary Table 2. Each reaction contained $1 \mu$ of cDNA product, $25 \mu \mathrm{l}$ of SYBR Green Supermix (100 mM KCl, $40 \mathrm{mM}$ Tris $\cdot \mathrm{HCl}, \mathrm{pH}$ 8.4, $0.4 \mathrm{mM}$ dNTP, 50 units/ml iTaq DNA polymerase, $6 \mathrm{mM} \mathrm{MgCl}_{2}$, SYBR Green I, $20 \mathrm{nM}$ fluorescein) (Bio-Rad Laboratories), and $100 \mathrm{nM}$ of forward and reverse primers. For each primer, a standard curve was generated, and $\beta$-actin primers were used as a housekeeping gene to allow quantification. Alterations in gene expression in treated cells were expressed relative to the mean intensity in the control cells, which was given a standardized value of 1. Data were statistically analyzed by the Mann-Whitney $U$-test, with a $P$ value of $<0.05$ considered significant. Negative controls consisting of reactions without cDNA template were included.

Immunohistochemistry. Five normal human metanephroi (9-10 wk gestation) were fixed in $4 \%$ paraformaldehyde, dehydrated, waxembedded, and sectioned at $5 \mu \mathrm{m}$. Sections were dewaxed and rehydrated, and antigens were unmasked by treatment with proteinase $\mathrm{K}(20 \mu \mathrm{g} / \mathrm{ml})$, protease $(20 \mu \mathrm{g} / \mathrm{ml})$, or microwaved in citric acid $(2.1$ $\mathrm{g} / \mathrm{l}, \mathrm{pH}$ 6.0), depending on the antibody used. Slides were treated with $3 \%$ hydrogen peroxide in distilled water to quench endogenous peroxidase. Nonspecific binding was blocked by incubation with $10 \%$ FCS, $0.2 \%$ bovine serum albumin, and $0.1 \%$ Tween 20 in phosphatebuffered saline for $30 \mathrm{~min}$ before overnight incubation at $4{ }^{\circ} \mathrm{C}$ with goat anti-human LIF (1:100; Santa Cruz Biotechnology, Santa Cruz, CA), goat anti-human LIFR (1:500, Santa Cruz Biotechnology), rabbit anti-human gp130 (1:200, Santa Cruz Biotechnology), rabbit antihuman MMP1 (1:200; Chemicon, Temecula, CA), rabbit anti-human sprouty-4 (SPRY4; 1:100, Abcam, Cambridge, UK), rabbit antihuman midline-1 (MID1, 1:50; Orbigen, San Diego, CA), and goat anti-human stanniocalcin-1 (STC1, 1:50; Santa Cruz Biotechnology). As negative controls, primary antibodies were preincubated with excess immunizing peptides $(10: 1 \mathrm{wt} / \mathrm{wt})$ or they were omitted. Washed slides were exposed to secondary antibodies, which were detected using an EnVision kit (DAKO, High Wycombe, UK) fol- lowed by diaminobenzidine and finally counterstained with hematoxylin.

\section{RESULTS}

Characterization of mesenchymal cells. As assessed by RTPCR (Fig. 1), the unstimulated cell line expressed the mesenchymal markers WT1 and GDNF: They did not express Ecadherin, an epithelial marker, nor WNT11 and RET, ureteric bud markers. We noted that these cells, cultured in serum-free media, did not express PAX2, although our earlier studies demonstrated PAX2 expression when cultured in serum-containing media (28).

Expression of LIF in human renal development. Using RT-PCR, we found LIF and its two receptors (LIFR and gp130) to be expressed by the unstimulated renal mesenchymal cell line, and all three transcripts were detected in whole human metanephroi (Fig. 1). In tissue sections of first trimester metanephroi (10 wk gestation), LIF immunolocalized in the metanephric capsule and ureteric bud branches (Fig. 2A), LIFR was detected in nephrogenic mesenchyme and also stromal cells between tubules (Fig. 2B), and gp130 signal was detected in subsets of cells in nephrogenic mesenchyme, stroma, and ureteric bud branches (Fig. 2C).

Mesenchymal cells cultured with LIF, FGF2, and TGF- $\alpha$. Parallel cultures were performed and analyzed in triplicate in basal medium alone or media supplemented with LIF, FGF2, and TGF- $\alpha$. At the start of the observation period, cells at $\sim 70 \%$ confluence had a typical "mesenchymal" morphology with irregular, elongated outlines (Fig. 3, $A$ and $B$ ). All cultures became confluent over the next 3 days, and there were no gross 
Table 1. Upregulated genes of $>1.8$-fold (83 in total)

\begin{tabular}{|c|c|c|c|c|c|}
\hline Probe Set & Gene Name & Gene Symbol & GenBank & $P$ & Fold Change \\
\hline 204595_s_at & stanniocalcin 1 & STC1 & A 1300520 & 0.003 & 25.077 \\
\hline 230748_at & solute carrier family 16 , member 6 & SLC16A6 & A1873273 & 0.004 & 12.919 \\
\hline 214920_at & hypothetical protein LOC221981 & & R33964 & 0.007 & 10.210 \\
\hline 213493_at & sushi, nidogen and EGF-like domains I & FLJ00133 & BF509657 & 0.007 & 9.754 \\
\hline 230167_at & $\begin{array}{l}\text { A disintegrin-like and metalloprotease (reprolysin type) with } \\
\text { thrombospondin type } 1 \text { motif, } 14\end{array}$ & ADAMTS14 & W60649 & 0.008 & 7.717 \\
\hline 210815_s_at & calcitonin receptor-like & CALCRL & U17473 & 0.039 & 6.353 \\
\hline 209906_at & complement component 3 a receptor 1 & C3AR1 & U62027 & 0.035 & 6.038 \\
\hline 217428_s_at & collagen, type $\mathrm{X}$, alpha 1 (Schmid metaphyseal chondrodysplasia) & COL10A1 & X98568 & 0.026 & 6.001 \\
\hline 226722_at & family with sequence similarity 20 , member $\mathrm{C}$ & FAM20C & BE874872 & 0.042 & 5.830 \\
\hline 205932_s_at & msh homeo box homolog 1 (Drosophila) & MSX1 & NM_002448 & 0.002 & 5.613 \\
\hline 206376_at & solute carrier family 6 , member 15 & NTT73 & NM_018057 & 0.002 & 4.744 \\
\hline 217999_s_at & CDNA clone IMAGE:4514712, partial cds & PHLDA1 & NM_007350 & 0.003 & 4.629 \\
\hline 218678_at & nestin & NES & NM_024609 & 0.019 & 4.614 \\
\hline 205286_at & $\begin{array}{l}\text { transcription factor AP- } 2 \text { gamma (activating enhancer binding } \\
\text { protein } 2 \text { gamma) }\end{array}$ & TFAP2C & $\mathrm{U} 85658$ & 0.019 & 4.502 \\
\hline 235743_at & Hypothetical protein MGC61716 & & AA808178 & 0.003 & 4.374 \\
\hline 211668_s_at & plasminogen activator, urokinase & PLAU & K03226 & 0.002 & 4.359 \\
\hline 206331_at & calcitonin receptor-like & CALCRL & NM_005795 & 0.037 & 4.269 \\
\hline 219282_s_at & transient receptor potential cation channel, subfamily $\mathrm{V}$, member 2 & TRPV2 & NM_015930 & 0.032 & 4.213 \\
\hline 213338_at & Ras-induced senescence 1 & RIS1 & BF062629 & 0.003 & 4.168 \\
\hline 1568604_a_at & $\mathrm{Ca}^{2+}$-dependent secretion activator & CADPS & A1912173 & 0.042 & 4.165 \\
\hline 208893_s_at & dual specificity phosphatase 6 & DUSP6 & ВC005047 & 0.000 & 4.098 \\
\hline 221489_s_at & sprouty homolog 4 (Drosophila) & SPRY4 & W48843 & 0.000 & 4.035 \\
\hline 209789_at & coronin, actin binding protein, 2B & $\mathrm{CORO} 2 \mathrm{~B}$ & BF939649 & 0.005 & 3.590 \\
\hline 217995_at & sulfide quinone reductase-like (yeast) & SQRDL & NM_021199 & 0.009 & 3.552 \\
\hline 209732_at & C-type lectin domain family 2, member B & CLECSF2 & BC005254 & 0.000 & 3.551 \\
\hline 206429_at & coagulation factor II (thrombin) receptor-like 1 & F2RL1 & NM_005242 & 0.003 & 3.549 \\
\hline 210643_at & tumor necrosis factor (ligand) superfamily, member 11 & TNFSF11 & AF053712 & 0.027 & 3.541 \\
\hline 217590_s_at & transient receptor potential cation channel, subfamily A, member 1 & TRPA1 & AA502609 & 0.021 & 3.493 \\
\hline 214841_at & cornichon homolog 3 (Drosophila) & FLJ38993 & AF070524 & 0.007 & 3.403 \\
\hline 227145_at & lysyl oxidase-like 4 & LOXL4 & AW190565 & 0.042 & 3.363 \\
\hline 223333_s_at & angiopoietin-like 4 & ANGPTL4 & AF169312 & 0.027 & 3.286 \\
\hline 213716_s_at & secreted and transmembrane 1 & SECTM1 & BF939675 & 0.011 & 3.230 \\
\hline 213248_at & hypothetical protein & LOC221362 & AL577024 & 0.000 & 3.213 \\
\hline 160020_at & matrix metalloproteinase 14 (membrane-inserted) & & 4870053 & 0.042 & 3.189 \\
\hline 220334_at & regulator of G-protein signaling 17 & RGS17 & NM_012419 & 0.000 & 3.152 \\
\hline 201920_at & solute carrier family 20 (phosphate transporter), member 1 & SLC20A1 & NM_005415 & 0.002 & 3.139 \\
\hline 33304_at & interferon stimulated gene $20 \mathrm{kDa}$ & & 4866504 & 0.015 & 3.036 \\
\hline 206467_x_at & tumor necrosis factor receptor superfamily, member $6 \mathrm{~b}$, decoy & TNFRSF6B & NM_003823 & 0.019 & 2.977 \\
\hline 201860_s_at & plasminogen activator, tissue & PLAT & NM_000930 & 0.000 & 2.950 \\
\hline 202565_s_at & Supervillin & SVIL & NM_003174 & 0.044 & 2.945 \\
\hline 212875_s_at & chromosome 21 open reading frame 25 & & AP001745 & 0.018 & 2.877 \\
\hline 230494_at & Hypothetical gene supported by AK124342 & SLC20A1 & A1671885 & 0.008 & 2.864 \\
\hline 206298_at & Rho GTPase activating protein 22 & RhoGAP2 & NM_021226 & 0.003 & 2.826 \\
\hline 213848_at & dual-specificity phosphatase 7 & DUSP7 & A1655015 & 0.038 & 2.756 \\
\hline 206571_s_at & mitogen-activated protein kinase 4 & MAP4K4 & NM_004834 & 0.033 & 2.741 \\
\hline 230345_at & transcribed locus & & A1654547 & 0.002 & 2.610 \\
\hline 217997_at & pleckstrin homology-like domain, family A, member 1 & PHLDA1 & A1795908 & 0.012 & 2.598 \\
\hline 226034_at & Homo sapiens, clone IMAGE:3881549, mRNA & & BE222344 & 0.048 & 2.569 \\
\hline 222557_at & stathmin-like 3 & & AL353715 & 0.002 & 2.560 \\
\hline
\end{tabular}


Table 1. continued

\begin{tabular}{|c|c|c|c|c|c|}
\hline Probe Set & Gene Name & Gene Symbol & GenBank & $P$ & Fold Change \\
\hline 206385_s_at & ankyrin 3, node of Ranvier (ankyrin G) & ANK3 & NM_020987 & 0.009 & 2.556 \\
\hline 208025_s_at & high mobility group AT-hook 2 & HMGA2 & NM_003483 & 0.000 & 2.528 \\
\hline 202206_at & ADP ribosylation factor-like 7 & ARL7 & AW450363 & 0.042 & 2.527 \\
\hline 1554576_a_at & ets variant gene 4 (EIA enhancer binding protein, EIAF) & ETV4 & ВC007242 & 0.032 & 2.522 \\
\hline 212944_at & mitochondrial ribosomal protein S6 & MRPS6 & AK024896 & 0.00552 & 2.4730 \\
\hline 230372_at & hyaluronan synthase 2 & HAS2 & AI374739 & 0.0357 & 2.2492 \\
\hline 209493_at & PDZ domain containing 3 & PDZK3 & AF338650 & 0.00142 & 2.2331 \\
\hline 206074_s_at & high mobility group AT-hook 1 & HMGA1 & NM_002131 & 0.0369 & 2.1800 \\
\hline 1567224_at & $\begin{array}{l}\text { Lipoma cell line Li-538/SV40 ectopic sequence from HMG1-C } \\
\text { fusion mRNA } 3 \text { ' sequence }\end{array}$ & & U29113 & 0.0148 & 2.1488 \\
\hline 208891_at & dual-specificity phosphatase 6 & DUSP6 & ВC003143 & 0.017 & 2.1463 \\
\hline 208892_s_at & dual-specificity phosphatase 6 & DUSP6 & ВC003143 & 0.0315 & 1.9912 \\
\hline 236313_at & cyclin-dependent kinase inhibitor $2 \mathrm{~B}$ & CDKN2B & AW444761 & 0.0282 & 1.9884 \\
\hline 227345_at & $\begin{array}{l}\text { tumor necrosis factor receptor superfamily, member } 10 \mathrm{~d} \text {, decoy } \\
\text { with truncated death domain }\end{array}$ & TNFRSF10D & AI738556 & 0.0226 & 1.9467 \\
\hline 226075_at & SPRY domain-containing SOCS box protein & SSB1 & AF131840 & 0.0116 & 1.9176 \\
\hline 221569_at & Abelson helper integration site & AHI1 & AL136797 & 0.0333 & 1.8287 \\
\hline
\end{tabular}

Table 2. Downregulated genes of $>1.8$ fold-change (36 in total)

\begin{tabular}{|c|c|c|c|c|c|}
\hline Probe Set & Gene & Common & GenBank & $P$ & Fold Decrease \\
\hline 226021_at & retinol dehydrogenase 10 (all-trans) & RDH10 & AW150720 & 0.00781 & 3.776 \\
\hline 209496_at & retinoic acid receptor responder (tazarotene induced) 2 & RARRES2 & ВC000069 & 0.0254 & 3.711 \\
\hline 207980_s_at & $\begin{array}{l}\text { Cbp/p300-interacting transactivator, with Glu/Asp-rich } \\
\text { carboxy-terminal domain, } 2\end{array}$ & CITED2 & NM_006079 & 0.0432 & 3.487 \\
\hline 209631_s_at & $\begin{array}{l}\text { G protein-coupled receptor } 37 \text { (endothelin receptor type } \\
\text { B-like) }\end{array}$ & GPR37 & U87460 & 0.0192 & 3.274 \\
\hline 203636_at & midline 1 (Opitz/BBB syndrome) & MID1 & BE967532 & 0.0211 & 3.267 \\
\hline 213624_at & sphingomyelin phosphodiesterase, acid-like $3 \mathrm{~A}$ & SMPDL3A & AA 873600 & 0.0226 & 3.176 \\
\hline 203868_s_at & vascular cell adhesion molecule 1 & VCAM1 & NM_001078 & 0.00859 & 3.168 \\
\hline 227467_at & retinol dehydrogenase 10 (all-trans) & RDH10 & AV697515 & 0.00206 & 3.100 \\
\hline 223044_at & $\begin{array}{l}\text { solute carrier family } 40 \text { (iron-regulated transporter), } \\
\text { member } 1\end{array}$ & SLC40A1 & AL136944 & 0.0176 & 3.072 \\
\hline 208096_s_at & collagen, type XXI, alpha I /// collagen, type XXI, alpha 1 & COL21A1 & NM_030820 & 0.0391 & 3.063 \\
\hline 226435_at & papilin, proteoglycan-like sulfated glycoprotein & PAPLN & AU145309 & 0.0201 & 2.995 \\
\hline 208296_x_at & tumor necrosis factor, alpha-induced protein 8 & GG2-1 & NM_014350 & 0.00983 & 2.969 \\
\hline 219087_at & asporin (LRR class I) & ASPN & NM_017680 & 0.0439 & 2.958 \\
\hline 232298_at & Muscleblind-like (Drosophila) & MBNL1 & AK026494 & 0.0309 & 2.892 \\
\hline 210260_s_at & tumor necrosis factor, alpha-induced protein 8 & GG2-1 & BC005352 & 0.0441 & 2.871 \\
\hline 203637_s_at & midline 1 (Opitz/BBB syndrome) & MID1 & NM_000381 & 0.0282 & 2.800 \\
\hline 205609_at & angiopoietin 1 & ANGPT1 & NM_001146 & 0.0435 & 2.769 \\
\hline 212650_at & EH domain binding protein 1 & KIAA0903 & $\mathrm{BF} 116032$ & 0.00945 & 2.589 \\
\hline 231001_at & similar to RIKEN cDNA 1110018M03 & & AI755024 & 0.039 & 2.502 \\
\hline 204235_s_at & GULP, engulfment adaptor PTB domain containing I & CED-6 & AF200715 & 0.00142 & 2.493 \\
\hline 226311_at & $\begin{array}{l}\text { full-length cDNA clone CSODI014YH2I of Placenta Cot } \\
\text { 25-normalized of Homo sapiens (human) }\end{array}$ & & BF058422 & 0.0075 & 2.473 \\
\hline 205807_s_at & tuftelin I & TUFTI & NM_020127 & 0.0111 & 2.464 \\
\hline 203766_s_at & leiomodin I (smooth muscle) & LMOD1 & NM_012134 & 0.0438 & 2.416 \\
\hline 236599_at & $\begin{array}{l}\text { serine (or cysteine) proteinase inhibitor, clade } \mathrm{E} \text { (nexin, } \\
\text { plasminogen activator inhibitor type I), member } 2\end{array}$ & & AA $\overline{7} 03280$ & 0.00595 & 2.414 \\
\hline 210095_s_at & insulin-like growth factor binding protein 3 & IGFBP3 & M31159 & 0.00142 & 2.342 \\
\hline 227657_at & ring finger protein 150 & RNF150 & AA722069 & 0.0254 & 2.322 \\
\hline 205608_s_at & angiopoietin I & ANGPTI & U83508 & 0.0282 & 2.307 \\
\hline 228080_at & layilin & LOC143903 & BE856341 & 0.00552 & 2.281 \\
\hline 215913_s_at & GULP, engulfment adaptor PTB domain containing I & CED-6 & AK023668 & 0.0305 & 2.250 \\
\hline 230482_at & $\begin{array}{l}\text { sialyltransferase } 7 \text { ((alpha-N-acetylneuraminyl-2,3-beta- } \\
\text { galactosyl-1,3)-N-acetyl galactosaminide alpha-2,6- } \\
\text { sialyltransferase) E }\end{array}$ & SIAT7E & AF 131837 & 0.0134 & 2.193 \\
\hline 203586_s_at & ADP ribosylation factor 4 -like & ARF4L & NM_001661 & 0.0435 & 2.189 \\
\hline 202016_at & mesoderm specific transcript homolog (mouse) & MEST & NM_002402 & 0.00164 & 2.187 \\
\hline 212653_s_at & EH domain binding protein I & KIAA0903 & AB020710 & 0.00985 & 2.169 \\
\hline 228367_at & alpha-kinase 2 & HAK & BE551416 & 0.0301 & 2.144 \\
\hline 218162_at & olfactomedin-like 3 & HNOEL-iso & NM_020190 & 0.0242 & 2.121 \\
\hline 213348_at & cyclin-dependent kinase inhibitor IC (p57, Kip2) & CDKN1C & N33167 & 0.0331 & 1.873 \\
\hline
\end{tabular}



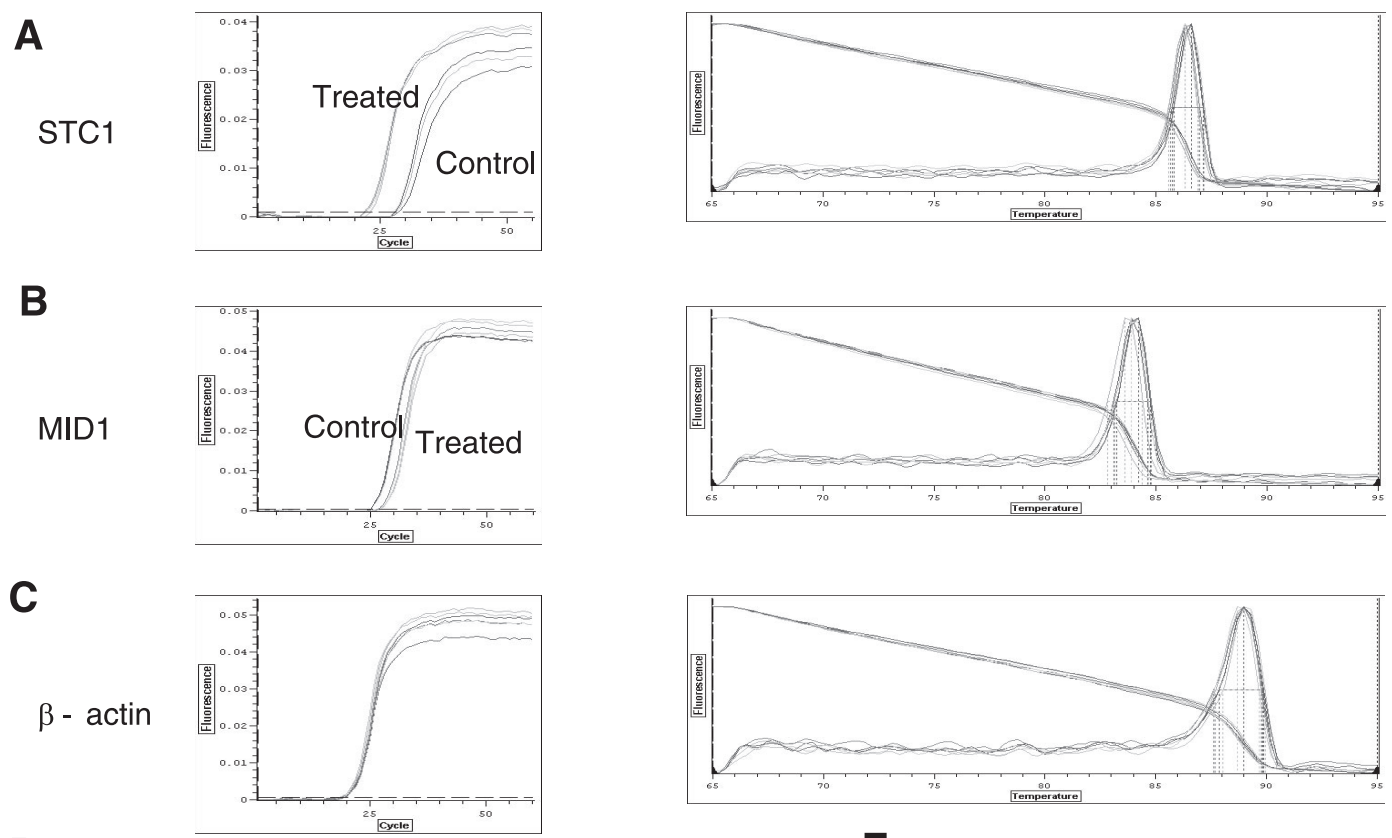

D

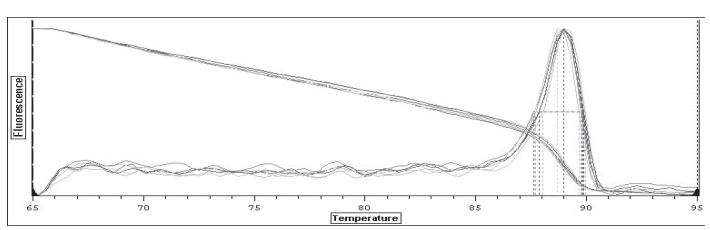

E
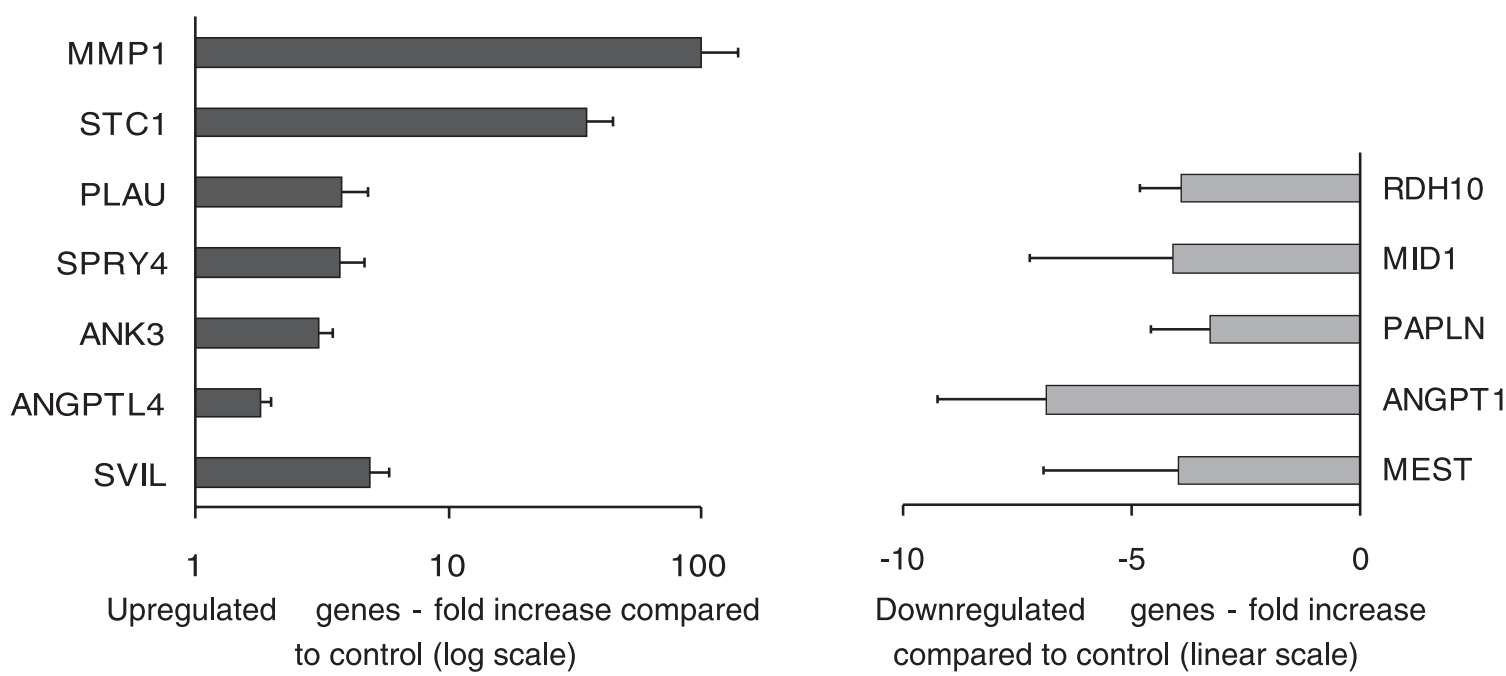

Fig. 4. Quantitative real-time PCR on selected genes. Left-hand panels in $A-C$ show fluorescence in treated and control samples for stanniocalcin (STC)1, midline (MID)1, and $\beta$-actin, whereas the corresponding right-hand panels show the melting curve for each of the primer sets. D: 7 upregulated genes; $E: 5$ downregulated genes.

changes in cell morphology in either treated or control groups, although those in basal medium alone tended to form randomly aligned elongated cells (Fig. 3C), whereas those exposed to LIF, FGF2, and TGF- $\alpha$ appeared to take up a more aligned conformation (Fig. 3D). To assess changes in gene expression in LIF/FGF2/TGF- $\alpha$-treated vs. control cells, we undertook microarray analysis $72 \mathrm{~h}$ after stimulation $(n=3$ for each group; Tables 1 and 2). Eighty-three genes showed statistically significant increases of $>1.8$ fold in treated cells, while 36 genes were downregulated using the same criteria. Changes were observed for: 1) genes modulating diverse cellular processes, particularly MMP1 and STC1, which were the two most highly upregulated genes at 78 - and 20- to 25-fold respectively; 2) genes previously implicated in organogenesis e.g., muscle-segment homeobox (msh) homeobox homolog 1 (MSX1; upregulated $\times 5.6$ ), nestin (upregulated $\times 4.6$ ), SPRY4 (upregulated $\times 4.0$ ), and MID1 (downregulated $\times 3.3$ ); and 3) genes involved in blood vessel growth e.g., angiopoietinlike factor 4 (ANGPTL4, upregulated $\times 3.3$ ), angiopoietin 1 (ANGPT1, downregulated $\times 2.3$ ), and vascular cell adhesion molecule 1 (VCAM1, downregulated $\times 3.2$ ). The full data set has been submitted to the ArrayExpress database at the European Bioinformatics Institute. Real-time quantitative RT-PCR was performed on 12 selected genes of biological interest, seven of which were upregulated and the remainder downregulated (Fig. 4). This technique confirmed directions and magnitudes of change suggested by the microarray analysis.

Expression of selected target genes in whole metanephroi. A striking feature of our results, obtained using cultured cells, was how few of the genes identified had previously been highlighted in early (i.e., first trimester) human nephrogenesis. Using RT-PCR we therefore sought, and confirmed, expression 
of the 12 genes alluded to above in whole metanephroi isolated at 9 and 12 wk gestation (Fig. 5). Additionally, we sought expression of selected genes using immunohistochemistry in sections from similarly staged metanephroi (9-10 wk gestation). First, for comparison, we demonstrated that WT1 immunolocalized to subsets of cells in the nephrogenic mesenchyme and was upregulated in condensed mesenchyme (Fig. 6, A and $B$ ), as previously described (39). Of the factors upregulated in treated cells, SPRY4, MMP1, and STC1 were immunolocalized in several areas including renal mesenchyme (Fig. 6, $C-J$ ). For MID1, which was downregulated in treated cells, subsets of positive cells were detected in the renal capsule and nephrogenic mesenchyme (Fig. $6, K$ and $L$ ).

\section{DISCUSSION}

Treatment of our human renal mesenchymal cells with a combination of LIF/FGF2/TGF- $\alpha$ induced a series of reproducible and significant changes in expression of numerous genes. Our in vitro and in vivo data have identified several previously unhighlighted genes which may be implicated in first trimester human nephrogenesis.

Barasch and colleagues demonstrated that LIF is expressed by murine ureteric bud cells, with mesenchyme expressing its receptors. In addition, administration of FGF2 and TGF- $\alpha$ to isolated mesenchymes prevented apoptosis but, in combination with LIF, led to differentiation with upregulation of the epithelial marker E-cadherin and formation of primitive tubules within $48 \mathrm{~h}$ (4). An earlier report, using whole metanephric explants, reported that LIF inhibited nephrogenesis (5); the apparent conflicts between these studies might be explained by confounding (negative) regulatory effects of LIF on the bud itself, or by differences in the concentration of added growth factor.

In the current study, we present the first report of expression of LIF and its receptors in the human metanephros. LIF was immunodetected in the ureteric bud, as in the mouse (4), but we also detected strong signal in the renal capsule. The capsule has recently been reported to contain Foxd1-positive cells and be essential for normal renal development (21). LIFR and gp130 were detected in mesenchyme and stroma of human metanephroi, with the latter protein also found in ureteric bud branches. Thus, in vivo, both human mesenchymal and bud lineages might be targets for LIF, although it is notable that gp130 can also bind several other interleukin-6 family members not sought in this study (24).

The renal mesenchymal cell line used in the current experiments also expressed both LIF receptors, providing a rationale for treatment with LIF (along with FGF2 and TGF- $\alpha$ ). Our initial analyses showed that they expressed both WT1 and GDNF, markers of renal mesenchyme, but not E-cadherin, an epithelial marker, nor ureteric bud markers RET and WNT11. This expression profile is unlike rodent lines such as the 7.1.1 metanephric cells, which express both mesenchymal and epithelial markers (25), and is consistent with the contention that the human cell line represents undifferentiated renal mesenchyme. This impression is also supported by the disorganized morphology of the cells in monolayer culture.

Following exposure of the human cell line to LIF, FGF2, and TGF- $\alpha, 83$ and 36 genes were up- or downregulated, respectively, as assessed by microarray analysis. The two factors with

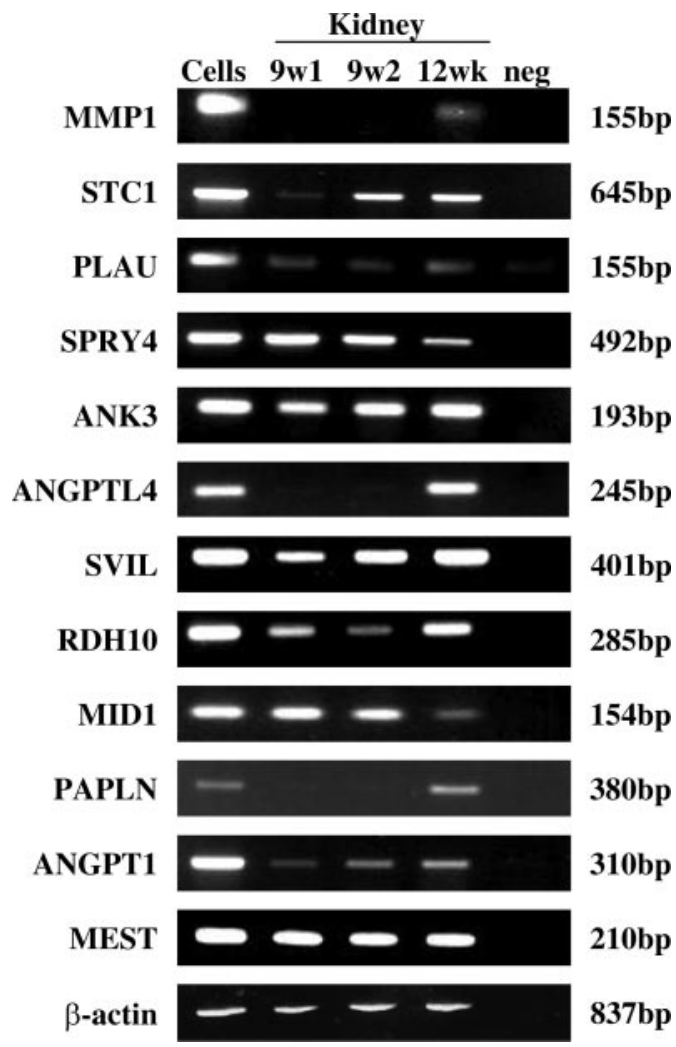

Fig. 5. Expression of selected target genes in whole metanephroi. RT-PCR performed in the control cell line (Cells) and in 2 human fetal kidneys at 9 wk (9w1 and 9w2) and 12 wk (12wk) of gestation. All target genes were detected at both stages in vivo, apart from matrix metalloproteinase (MMP)1, angiopoietin-like factor (ANGPTL)4, and PAPLN, which were only detected at 12 wk gestation.

the highest change in expression levels following stimulation were MMP1 and STC1. Appropriate breakdown of the extracellular matrix is a critical process in development and MMP1 degrades collagens, aggrecan, proteoglycans, and tenascin (34). Little is known about MMP1 in renal development, but because there is no direct homolog in mice (2), the current insight could not have been elicited in murine studies. Intriguingly, MMP1 was not detected at 9 wk gestation by RT-PCR, but positive immunostaining was detected at $10 \mathrm{wk}$ (and RT-PCR at $12 \mathrm{wk}$ ). It would be interesting to repeat these studies with several samples at each time point to assess whether this upregulation occurs consistently, but, unfortunately, sufficient material is not available to study. A related protease, MMP14, was also significantly upregulated $(\times 3.2)$ and has been reported to be expressed in mouse metanephroi (26). STC1 is a polypeptide hormone regulating phosphate and calcium flux in diverse tissues. Previous studies in mature human kidneys demonstrated expression in principal and $\alpha$-intercalated cells (11), but metanephric expression has only previously been reported in rodents (40). In the mouse metanephros, STC1 mRNA is first detected in mesenchyme but is later restricted to ureteric bud derivatives; protein is more widely distributed (13), as might be expected for a secreted protein. Based on expression patterns, it has been speculated that STC1 has a possible role in differentiation in mouse urogenital development and our results raise the same possibility in humans. 

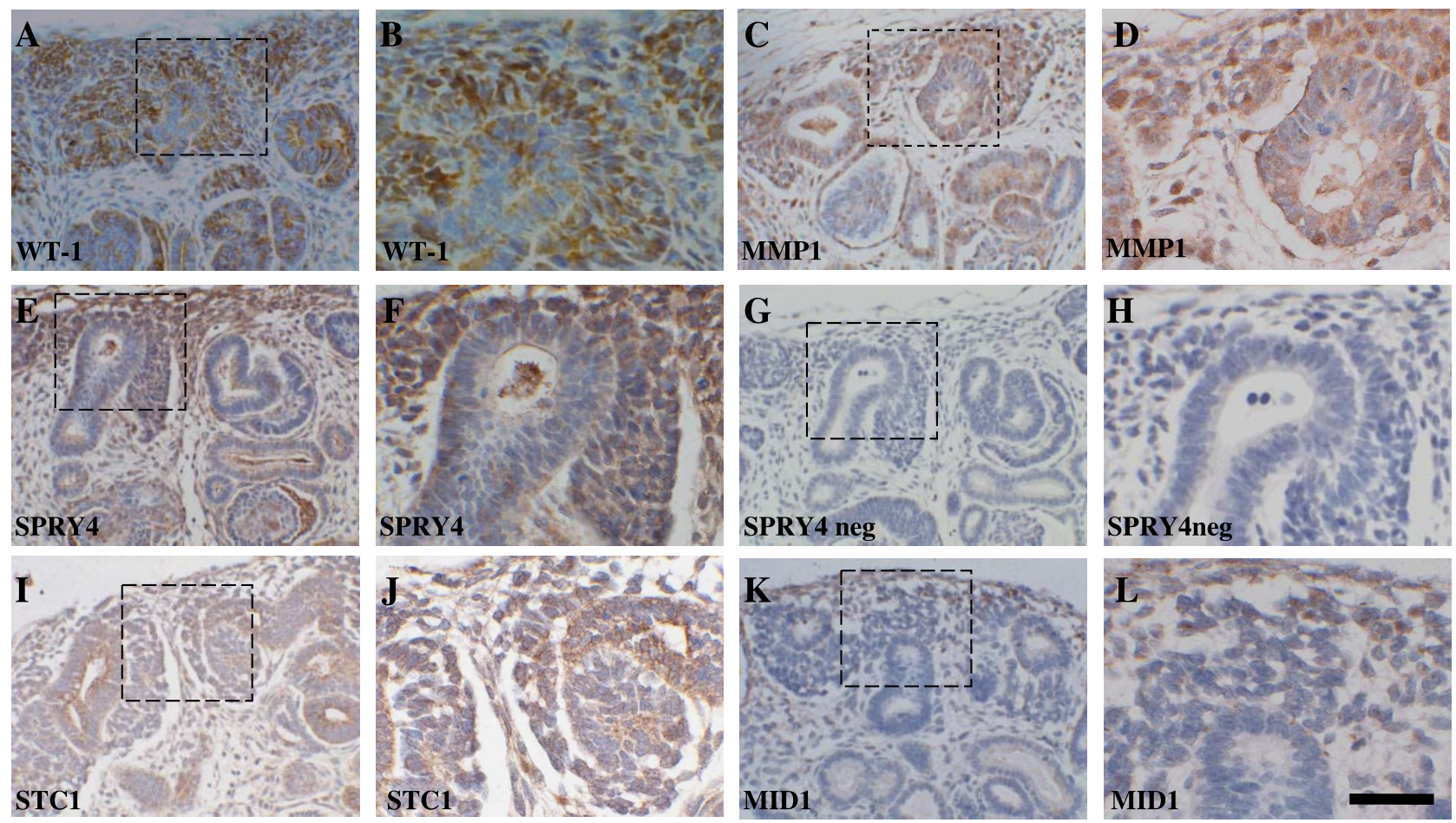

Fig. 6. Immunohistochemistry of human metanephroi. We used 10-wk-old human fetal kidneys for all antibodies, with the exception of STC1 where a 9-wk-old kidney was used. All sections counterstained with hematoxylin: positive immunohistochemical signal is brown. $A, C, E, G, I$, and $K$ are low-power views of the metanephric cortex, whereas $B, D, F, H, J$, and $L$ are enlarged frames of regions of interest. $A$ and $B$ : WT1 in subsets of cells in nephrogenic mesenchyme and in condensed mesenchyme. Note nonspecific background staining in ureteric bud. $C$ and $D$ : MMP1 in subsets of nephrogenic mesenchyme cells. $E$ and $F$ : sprouty (SPRY) 4 in nephrogenic and condensed mesenchyme. $G$ and $H$ : negative control for SPRY4. $I$ and $J$ : STC1 immunolocalized in mesenchyme and ureteric bud branches. $K$ and $L$ : MID1 in the capsule and subsets of nephrogenic mesenchyme cells. Bar is $50 \mu \mathrm{m}$ for low-powered views and $15 \mu \mathrm{m}$ for enlarged frames of regions of interest.

The two most downregulated genes in our cells following stimulation were RDH10 and RARRES2. Retinoid signaling is important in renal development, modulating ureteric bud division and final nephron complement (15), and lower urinary tract morphogenesis (7). Exposure of pregnant mice to all-trans retinoic acid in midgestation causes a failure of renal mesenchyme to express WT1 along with fulminant apoptosis (36). The next most downregulated factor was CITED2, a member of the CITED family of nuclear transactivators. CITED2 has been shown to modulate MMP levels in vitro in an immortalized human chondrocyte cell line, with increased CITED2 linked to a fall in MMP1 mRNA and protein levels via a TGF- $\beta$-dependent pathway (45); here we observed a similar converse relationship as the significant fall in CITED2 occurred in conjunction with a massive increase in MMP1.

The MSX1 gene was upregulated $\times 5.6$ after 3 days. Msx genes are a family of homeobox-containing factors related to the Drosophila msh that are expressed in diverse vertebrate tissues, including neural crest, bone, and teeth. MSX1 has not previously been reported in human kidney cells, but several of its interacting partners including BMP and WNT family members are important in nephrogenesis (42). Mutations of MID1 are the cause of the X-linked Opitz G/BBB syndrome, which comprises defects of the ventral midline such as hypertelorism, cleft lip/palate, and heart malformations (33). MID1 was downregulated $\times 3.3$ on microarray and is known to be associated with microtubules (30) and catalyses degradation of protein phosphatase $2 \mathrm{~A}(\mathrm{PP} 2 \mathrm{Ac})$, a central cellular regulator (35).
Nestin (two transcripts upregulated $\times 2.2$ and $\times 4.6$ ) is an intermediate filament protein classically associated with neuroepithelial stem cells that is now recognized in multilineage progenitor cells (38). Recent reports describe mesenchymal expression at the inception of mouse metanephrogenesis with subsequent expression in podocytes (10). Numerous processes including proliferation, differentiation, migration, and survival are controlled by receptor tyrosine kinase signaling pathways, and the Spry proteins are ligand-inducible inhibitors of these systems (23). We detected significant upregulation of SPRY4 (4.0x) upon exposure to LIF/FGF2/TGF- $\alpha$. Several reports have implicated SPRY4 in lung development, where it is expressed in mesenchyme and may antagonize FGF signaling. In the murine kidney, it is also expressed at the tips of the ureteric bud and adjacent mesenchyme (46). SPRY domaincontaining SOCS box protein was also significantly upregulated (1.9-fold). Interestingly, SPRY1 mRNA was also upregulated 2.5-fold on microarray, although the $P$ value for this change was just above our cut-off value of 0.05 ; this factor is thought to modulate GDNF/RET signaling (6), an important process in kidney development as mutations in either of these factors causes renal agenesis.

Alterations in several angiogenic genes were also observed following treatment. The developmental origins of the renal vasculature is much debated with initial suggestions that all of the vessels grew into the kidney by angiogenesis, based on transplantation experiments in the chick, refuted by the finding of vascular precursors within the early metanephros (22) and in metanephric mesenchymal cell lines (37). We detected 
changes in expression of several "vascular factors" after exposure to LIF/FGF2/TGF- $\alpha$. ANGPTL4 was upregulated, whereas VCAM1 and ANGPT1 were decreased. ANGPTL4 is a strongly proangiogenic, hypoxia-inducible factor, and high levels have been described in renal cell carcinoma (20). ANGPT1 is a secreted growth factor that enhances endothelial cell survival and capillary morphogenesis, and expression has already been confirmed in the murine metanephros (43). VCAM1 is expressed in glomerular parietal cells, proximal tubules, and endothelia of mature kidneys (32), and angiotensin II-driven upregulation occurs in diverse renal conditions (19). These are not the only factors associated with vessel development, however, as several of the previously detailed genes may also be implicated. Examples include MMPs, which are important in degradation of the vascular basement membrane and matrix remodeling to facilitate endothelial cell migration (29), and nestin, which has been described in nascent skin blood vessels (1) and in glomerular vascular precursors (10).

Despite these highly significant changes in expression of diverse factors, we did not observe either gross morphological changes in the cells or upregulation of epithelial markers such as collagen IV, cadherin-6, or E-cadherin following treatment, which contrasts markedly with rodent studies $(4,27,44)$. These discrepancies raise intriguing questions about potential differences between human and rodent kidney development, but, to inform and design future studies, we must also consider other possible reasons why these human cells failed to differentiate. Firstly, we may have used the wrong subset of cells. Although our cell lines have several renal mesenchymal characteristics alluded to above, they did not express either PAX2 or WNT4 (as assessed on microarray; data not shown) in serum-free conditions, markers of the nephron lineage in rodent studies $(27,44)$. Interestingly, we previously reported that the same line expressed PAX2 when propagated in serum-containing media (28), and Drummond et al. (14) showed that fetal calf serum was crucial to induce renal mesenchymal differentiation and could enhance expression of epithelium-specific genes. Secondly, the combination of growth factors used may have been insufficient to induce human differentiation. Differentiation has only been demonstrated with these factors in rat mesenchymes and is less successful in mice (4), so perhaps human cells needed a modified regimen. LIF responsiveness appears linked to upregulation of cadherin 16, at least for adult murine renal mesenchymal differentiation (16), and this factor was actually downregulated 1.7 -fold by treatment here (data not shown). Clearly, other growth factor combinations could be assessed in future and potential factors worthy of consideration are retinoic acid, activin-A, and bone morphogenetic protein 7 because embryonic stem cells treated with this combination are capable of differentiating into kidney epithelia (18). Finally, specific cell substrata may be critical for differentiation. Uncoated tissue culture plastic was used in these experiments, but perhaps coating dishes with collagen I or IV, growing the cells on filters, or culture in gels would be more efficacious.

In summary, we report expression of components of the LIF-signaling pathway for the first time in developing human kidneys and investigated the potential differentiation of human renal mesenchymal cells in response to a combination of growth factors including LIF. Our observations concerning changes of human gene expression, ascertained initially in vitro and then confirmed in whole organs, uncover several novel candidates that may be important in understanding pathways of early human nephrogenesis.

\section{GRANTS}

Kidney Research UK (R18/1/2000), Kids Kidney Appeal, Special Trustees, Great Ormond Street Hospital, UCL Institute of Child Health Human Developmental Biology Resource.

\section{REFERENCES}

1. Amoh Y, Li L, Yang M, Moossa AR, Katsuoka K, Penman S, Hoffman RM. Nascent blood vessels in the skin arise from nestin-expressing hair-follicle cells. Proc Natl Acad Sci USA 101: 13291-13295, 2004.

2. Balbin M, Fueyo A, Knauper V, Lopez JM, Alvarez J, Sanchez LM, Quesada V, Bordallo J, Murphy G, Lopez-Otin C. Identification and enzymatic characterization of two diverging murine counterparts of human interstitial collagenase (MMP-1) expressed at sites of embryo implantation. J Biol Chem 276: 10253-10262, 2001.

3. Barasch J, Pressler L, Connor J, Malik A. A ureteric bud cell line induces nephrogenesis in two steps by two distinct signals. Am J Physiol Renal Fluid Electrolyte Physiol 271: F50-F61, 1996.

4. Barasch J, Yang J, Ware CB, Taga T, Yoshida K, ErdjumentBromage H, Tempst P, Parravicini E, Malach S, Aranoff T, Oliver JA. Mesenchymal to epithelial conversion in rat metanephros is induced by LIF. Cell 99: 377-386, 1999.

5. Bard JB, Ross AS. LIF, the ES-cell inhibition factor, reversibly blocks nephrogenesis in cultured mouse kidney rudiments. Development 113: 193-198, 1991.

6. Basson MA, Akbulut S, Watson-Johnson J, Simon R, Carroll TJ, Shakya R, Gross I, Martin GR, Lufkin T, McMahon AP, Wilson PD, Costantini FD, Mason IJ, Licht JD. Sprouty1 is a critical regulator of GDNF/RET-mediated kidney induction. Dev Cell 8: 229-239, 2005.

7. Batourina E, Tsai S, Lambert S, Sprenkle P, Viana R, Dutta S, Hensle T, Wang F, Niederreither K, McMahon AP, Carroll TJ, Mendelsohn CL. Apoptosis induced by vitamin A signaling is crucial for connecting the ureters to the bladder. Nat Genet 37: 1082-1089, 2005.

8. Burrow C, Wilson PD. A putative Wilms tumor-secreted growth factor activity required for primary culture of human nephroblasts. Proc Natl Acad Sci USA 90: 6066-6070, 1993.

9. Bush KT, Sakurai H, Steer DL, Leonard MO, Sampogna RV, Meyer TN, Schwesinger C, Qiao J, Nigam SK. TGF-beta superfamily members modulate growth, branching, shaping, and patterning of the ureteric bud. Dev Biol 266: 285-298, 2004.

10. Chen J, Boyle S, Zhao M, Su W, Takahashi K, Davis L, Decaestecker M, Takahashi T, Breyer MD, Hao CM. Differential expression of the intermediate filament protein nestin during renal development and its localization in adult podocytes. J Am Soc Nephrol 17: 1283-1291, 2006.

11. De Niu P, Olsen HS, Gentz R, Wagner GF. Immunolocalization of stanniocalcin in human kidney. Mol Cell Endocrinol 137: 155-159, 1998.

12. Dekel B, Burakova T, Arditti FD, Reich-Zeliger S, Milstein O, AvielRonen S, Rechavi G, Friedman N, Kaminski N, Passwell JH, Reisner Y. Human and porcine early kidney precursors as a new source for transplantation. Nat Med 9: 53-60, 2003.

13. Deol H, Stasko SE, De Niu P, James KA, Wagner GF. Post-natal ontogeny of stanniocalcin gene expression in rodent kidney and regulation by dietary calcium and phosphate. Kidney Int 60: 2142-2152, 2001.

14. Drummond IA, Goodyer P, Sukhatme VP. Immortal, developmentally arrested human fetal kidney cell lines created by retroviral expression of human papilloma virus E6 and E7. Exp Nephrol 5: 390-398, 1997.

15. Gilbert T, Merlet-Benichou C. Retinoids and nephron mass control. Pediatr Nephrol 14: 1137-1144, 2000.

16. Hishikawa K, Marumo T, Miura S, Nakanishi A, Matsuzaki Y, Shibata K, Kohike H, Komori T, Hayashi M, Nakaki T, Nakauchi H, Okano H, Fujita T. Leukemia inhibitory factor induces multi-lineage differentiation of adult stem-like cells in kidney via kidney-specific cadherin 16. Biochem Biophys Res Commun 328: 288-291, 2005.

17. Ivins S, Lammerts vB, Roberts C, James C, Lindsay E, Baldini A, Ataliotis P, Scambler PJ. Microarray analysis detects differentially expressed genes in the pharyngeal region of mice lacking Tbx1. Dev Biol 285: 554-569, 2005.

18. Kim D, Dressler GR. Nephrogenic factors promote differentiation of mouse embryonic stem cells into renal epithelia. J Am Soc Nephrol 16: 3527-3534, 2005. 
19. Klahr S, Morrissey JJ. The role of vasoactive compounds, growth factors and cytokines in the progression of renal disease. Kidney Int Suppl 75: S7-S14, 2000

20. Le Jan S, Amy C, Cazes A, Monnot C, Lamande N, Favier J, Philippe J, Sibony M, Gasc JM, Corvol P, Germain S. Angiopoietin-like 4 is a proangiogenic factor produced during ischemia and in conventional renal cell carcinoma. Am J Pathol 162: 1521-1528, 2003.

21. Levinson RS, Batourina E, Choi C, Vorontchikhina M, Kitajewski J, Mendelsohn CL. Foxd1-dependent signals control cellularity in the renal capsule, a structure required for normal renal development. Development 132: 529-539, 2005.

22. Loughna S, Hardman P, Landels E, Jussila L, Alitalo K, Woolf AS. A molecular and genetic analysis of renal glomerular kidney development. Angiogenesis 1: 84-101, 1997.

23. Mason JM, Morrison DJ, Basson MA, Licht JD. Sprouty proteins: multifaceted negative-feedback regulators of receptor tyrosine kinase signaling. Trends Cell Biol 16: 45-54, 2006.

24. Metcalf D. The unsolved enigmas of leukemia inhibitory factor. Stem Cells 21: 5-14, 2003.

25. Oliver JA, Barasch J, Yang J, Herzlinger D, Al Awqati Q. Metanephric mesenchyme contains embryonic renal stem cells. Am J Physiol Renal Physiol 283: F799-F809, 2002.

26. Ota K, Stetler-Stevenson WG, Yang Q, Kumar A, Wada J, Kashihara N, Wallner EI, Kanwar YS. Cloning of murine membrane-type-1-matrix metalloproteinase (MT-1-MMP) and its metanephric developmental regulation with respect to MMP-2 and its inhibitor. Kidney Int 54: 131-142, 1998.

27. Plisov SY, Yoshino K, Dove LF, Higinbotham KG, Rubin JS, Perantoni AO. TGF beta 2, LIF and FGF2 cooperate to induce nephrogenesis. Development 128: 1045-1057, 2001.

28. Romio L, Wright V, Price K, Winyard PJ, Donnai D, Porteous ME, Franco B, Giorgio G, Malcolm S, Woolf AS, Feather SA. OFD1, the gene mutated in Oral-Facial-Digital syndrome type 1, Is expressed in the metanephros and in human embryonic renal mesenchymal cells. J Am Soc Nephrol 14: 680-689, 2003.

29. Rundhaug JE. Matrix metalloproteinases and angiogenesis. J Cell Mol Med 9: 267-285, 2005

30. Schweiger S, Foerster J, Lehmann T, Suckow V, Muller YA, Walter G, Davies T, Porter H, van Bokhoven H, Lunt PW, Traub P, Ropers HH. The Opitz syndrome gene product, MID1, associates with microtubules. Proc Natl Acad Sci USA 96: 2794-2799, 1999.

31. Seo J, Bakay M, Chen YW, Hilmer S, Shneiderman B, Hoffman EP. Interactively optimizing signal-to-noise ratios in expression profiling: project-specific algorithm selection and detection p-value weighting in Affymetrix microarrays. Bioinformatics 20: 2534-2544, 2004.

32. Seron D, Cameron JS, Haskard DO. Expression of VCAM-1 in the normal and diseased kidney. Nephrol Dial Transplant 6: 917-922, 1991.
33. So J, Suckow V, Kijas Z, Kalscheuer V, Moser B, Winter J, Baars M, Firth H, Lunt P, Hamel B, Meinecke P, Moraine C, Odent S, Schinzel A, van der Smagt JJ, Devriendt K, Albrecht B, Gillessen-Kaesbach G, van dB, I, Petrij F, Faivre L, McGaughran J, McKenzie F, Opitz JM, Cox T, Schweiger S. Mild phenotypes in a series of patients with Opitz GBBB syndrome with MID1 mutations. Am J Med Genet A 132: 1-7, 2005.

34. Somerville RP, Oblander SA, Apte SS. Matrix metalloproteinases: old dogs with new tricks. Genome Biol 4: 216, 2003.

35. Trockenbacher A, Suckow V, Foerster J, Winter J, Krauss S, Ropers HH, Schneider R, Schweiger S. MID1, mutated in Opitz syndrome, encodes an ubiquitin ligase that targets phosphatase $2 \mathrm{~A}$ for degradation. Nat Genet 29: 287-294, 2001.

36. Tse HK, Leung MB, Woolf AS, Menke AL, Hastie ND, Gosling JA, Pang CP, Shum AS. Implication of Wt1 in the pathogenesis of nephrogenic failure in a mouse model of retinoic acid-induced caudal regression syndrome. Am J Pathol 166: 1295-1307, 2005.

37. Usui J, Yamada R, Kanemoto K, Koyama A, Nagata M. Murine metanephric mesenchyme possesses characteristics of vascular endothelial cells in vitro. Nephron Exp Nephrol 102: e93-e98, 2006.

38. Wiese C, Rolletschek A, Kania G, Blyszczuk P, Tarasov KV, Tarasova Y, Wersto RP, Boheler KR, Wobus AM. Nestin expression-a property of multi-lineage progenitor cells? Cell Mol Life Sci 61: 2510-2522, 2004.

39. Winyard PJD, Risdon RA, Sams VR, Dressler G, Woolf AS. The PAX2 transcription factor is expressed in cystic and hyperproliferative dysplastic epithelia in human kidney malformations. J Clin Invest 98: 451-459, 1996.

40. Wong CK, Ho MA, Wagner GF. The co-localization of stanniocalcin protein, mRNA and kidney cell markers in the rat kidney. $J$ Endocrinol 158: 183-189, 1998.

41. Woolf AS, Jenkins D. Development of the kidney. In: Heptinstall's Pathology of the Kidney, edited by Jennette JC, Olson JL, Schwartz MM, and Silva FG. Philadelphia-New York: Lippincott-Raven, 2006, p. 70-95.

42. Woolf AS, Price KL, Scambler PJ, Winyard PJ. Evolving concepts in human renal dysplasia. J Am Soc Nephrol 15: 998-1007, 2004.

43. Woolf AS, Yuan HT. Angiopoietin growth factors and Tie receptor tyrosine kinases in renal vascular development. Pediatr Nephrol 16: 177-184, 2001.

44. Yang J, Blum A, Novak T, Levinson R, Lai E, Barasch J. An epithelial precursor is regulated by the ureteric bud and by the renal stroma. Dev Biol 246: 296-310, 2002.

45. Yokota H, Goldring MB, Sun HB. CITED2-mediated regulation of MMP-1 and MMP-13 in human chondrocytes under flow shear. $J$ Biol Chem 278: 47275-47280, 2003.

46. Zhang S, Lin Y, Itaranta P, Yagi A, Vainio S. Expression of Sprouty genes 1, 2 and 4 during mouse organogenesis. Mech Dev 109: 367-370, 2001 . 